\title{
Assessing Market Development and Innovation Project Management Factors Using the PICEA-g Hybrid Evolutionary Multi-Criteria Decision Technique
}

\author{
The Calcimine Company Case Study
}

\author{
Saeed Ghaffari \\ Department of Industrial Engineering \\ Payam-e-Noor University \\ Tehran, Iran \\ saeed.ghaffari68@gmail.com
}

\author{
Amir Najafi \\ Department of Industrial Engineering \\ Zanjan Branch \\ Islamic Azad University \\ Zanjan, Iran \\ asdnjf@gmail.com
}

\author{
Meisam Jafari Eskandari \\ Department of Industrial Engineering \\ Payam-e-Noor University \\ Tehran, Iran \\ meisam_jafari@pnu.ac.ir
}

\begin{abstract}
Project management includes the consideration of complex decision modes used in modern decision support techniques. The aim of this paper was to prioritize such factors and evaluate their effects on project management and optimal control. Their effect on management and optimal project control are evaluated in frame of a statistical hypothesis. A new algorithm, "IPICEA-g" is proposed for the assessment. A questionnaire is used for data collection distributed between 56 employees of the CALCIMINE Company. T-test, two-sentence test, ANP method, FUZZY SEAMATEL and the IPICEA-g hybrid algorithm, are employed for data analyzing. Results are further discussed and conclusions are drawn.
\end{abstract}

Keywords-management; control; projects; hybrid; algorithm; IPICEA-g; DEAMATEL; fuzzy; ANP; marketing; development

\section{INTRODUCTION}

Project management uses two main strong arms: project planning and project control and it is widely accepted as an area of interdisciplinary nature. The central core of all project management activities is project control which is the main factor for distinguishing it from other areas of management [1]. A set of conditions and limitations are employed to make use of management knowledge in the field of project management while avoiding the creation of additional concepts or a new body of knowledge which would have little difference from their original version. The interference trend of project management can be investigated in three zones: production of project management knowledge, solutions for Enterprise Resource Planning and mobility of human resources [2]. The current paper investigates management elements for an optimal implementation in the case of Calcimine Company with the purpose of identifying and assessing such factors.
Authors in [3] investigated the affecting factors in delays of development projects. Authors in [4] studied the affecting factors on the success of knowledge management projects. Authors in [5] provided a model of such factors in the construction industry and explained the relationship between them. Author in [6] discussed the dynamic modeling of projects execution time and explored influencing factors on the delay through a system dynamics approach in both micro and macro levels. In [7], the harmonization of knowledge and project management was studied. A model in which the success of change initiatives is explained by the quality of project management, which in turn is determined by the quality of the knowledge integration, was presented. In [8] the viewpoints of shareholders about cost estimates in project management are discussed. The aim of this study was to identify key issues and provide a conceptual model. In [9], the issue of comprehensive systematic thinking in the innovative project management was investigated. Authors in [10] examined the integration of project management office role in the forefront of innovation. The effect of communications management on construction project performance was investigated in [11]. Authors in [12] investigated the project risk management approach in small companies. In [13], authors provided a new method for controlling projects under uncertainty with regard to returning to first principles. Authors in [14] employed framework analysis to evaluate the success of the knowledge-based project approach.

\section{RESEARCH METHODOLOGY}

The method of study is descriptive and in terms of achieving results is focused on the explorations. Information is collected through questionnaires sent to experts and engineers of the Calcimine Company Local market and project 
characteristics were considered for the selection of factor for the conceptual model (Figure 1).

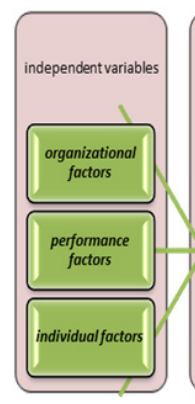

Fig. 1.

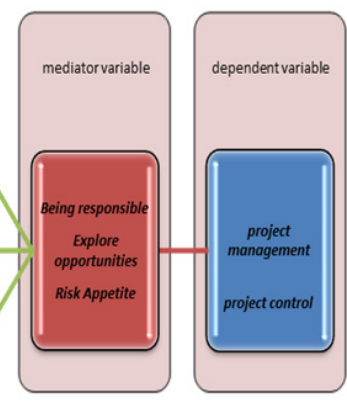

The conceptual model
Two questionnaires were sent to each of the 56 managers of the Calcimine Company selected to participate in this study. Of these, 11 were senior managers and $45 \mathrm{R} \& \mathrm{D}$ project managers. The first questionnaire follows a five-item Likert method that includes 11 questions in terms of organizational criteria, 12 questions in relation to performance criteria, 14 questions regarding personal standards and 8 questions regarding personal-group criteria. The second questionnaire contained 7 questions regarding organizational criteria, 10 questions in relation to performance metrics, 9 questions in relation to individual criteria, and 6 questions in relation to the criteria of the individual- groups and was designed considering the results from the first questionnaire. In terms of reliability and validity the Cranach's alpha coefficient of the questionnaire is shown in Table I. To study and analyze questionnaire answers the t-test and binomial test were employed. Then through a combination of ANP and fuzzy methods the weights of the objective functions were determined and finally through the implementation of the IPICEA-g hybrid algorithm, the prioritization of factors was achieved. SPSS and Matlab were the software used for the analysis.

TABLE I. THE RELIABILITY SCALE OF AFFECTING FACTORS ON PROJECT MANAGEMENT

\begin{tabular}{|c|c|c|}
\hline $\begin{array}{c}\text { Cranach's alpha } \\
\text { coefficients }\end{array}$ & Subscale & Row \\
\hline 0.82 & Organizational & 1 \\
\hline 0.79 & Functional & 2 \\
\hline 0.77 & Individual & 3 \\
\hline
\end{tabular}

\section{COMPUTATIONAL RESULTS}

\section{A. Descriptive Statistical Results}

$19.6 \%$ of the cases were female and $80.4 \%$ were male, $25 \%$ were under $30,41.1 \%$ were from 30 to 35 years old, $10.7 \%$ from 36 to $40,8.9 \%$ were from 41 to 45 and $14.3 \%$ from 46 and over. $32.1 \%$ owned a bachelor degree or less, $50 \%$ a master's and $17,9 \%$ owned a $\mathrm{PhD}$. As for the work experience $35.7 \%$ of people had work experience of 5 years and less, $23.2 \% 6$ to 10 years, $25 \% 11$ to 15 years, and $16.1 \%$ of them had work experience longer than 16 years.

\section{B. Results of Criteria and Indicators Monitoring and} Evaluation

$$
\begin{aligned}
& \text { The proportion of people who } \\
& \text { agree with the standard } \mathrm{X} \text {, }
\end{aligned}
$$

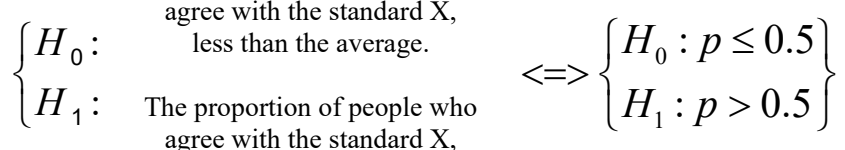

According to the binomial test, the most important affecting factors on project management and optimal control are shown in Table II. According to the binomial test, the main criteria for the effective functioning on the management and optimization control of project are shown in Table III. According to the binomial test, the most affecting individual measures on the management and optimization control of project are shown in Table IV and the most important affecting individual - group measures on the management and optimization control of project are shown in Table $\mathrm{V}$.

TABLE II. ORGANIZATIONAL AFFECTING FACTORS ON PROJECT MANAGEMENT AND OPTIMAL CONTROL

\begin{tabular}{|c|c|}
\hline ID & Functional Competencies \\
\hline $\mathrm{C} 8$ & Project Documentation \\
\hline C9 & Determining the project scope, registration and approval \\
\hline $\mathrm{C} 10$ & Choosing project structures \\
\hline $\mathrm{C} 11$ & Resource planning, registration and approval \\
\hline $\mathrm{C} 12$ & Select of qualified contractors and vendors \\
\hline $\mathrm{C} 13$ & Estimating project costs \\
\hline $\mathrm{C} 14$ & $\begin{array}{c}\text { Directing, managing of registration process and executing } \\
\text { contracts }\end{array}$ \\
\hline $\mathrm{C} 15$ & $\begin{array}{l}\text { Investigate, identify and implementation of necessary changes } \\
\text { in project }\end{array}$ \\
\hline $\mathrm{C} 16$ & $\begin{array}{l}\text { Coordination between different units and issuing guidelines } \\
\text { which related to projects }\end{array}$ \\
\hline $\mathrm{C} 17$ & Funding, resources and equipment needed to start the project \\
\hline
\end{tabular}

\begin{tabular}{|c|c|}
\hline ID & Knowledge Competence \\
\hline C1 & Understanding of project characteristics \\
\hline C2 & $\begin{array}{c}\text { Understanding of the assessment process and the feasibility of } \\
\text { the project }\end{array}$ \\
\hline C3 & Understanding of project structures \\
\hline C4 & Understanding the topic of project resources \\
\hline C5 & Understanding the concept of project time \\
\hline C6 & Understanding the budget issues and project costs \\
\hline C7 & Understanding the topic of project resources \\
\hline
\end{tabular}

TABLE III. PERFORMANCE CRITERIA FOR EFFECTIVE MANAGEMENT AND OPTIMAL CONTROL OF PROJECT

TABLE IV. AFFECTING INDIVIDUAL MEASURES ON THE MANAGEMENT AND OPTIMIZATION CONTROL OF PROJECT

\begin{tabular}{|c|c|}
\hline ID & Behavioral Competencies \\
\hline C18 & Hard work \\
\hline C19 & The spirit of achievement \\
\hline C20 & Initiative and innovation \\
\hline C21 & Self Confidence \\
\hline C22 & Result oriented \\
\hline C23 & Being regulated \\
\hline C24 & Having strategic perspectives \\
\hline C25 & Spirit of competition \\
\hline C26 & Having systematic approaches \\
\hline
\end{tabular}


TABLE V. AFFECTING INDIVIDUAL - GROUP MEASURES ON THE MANAGEMENT AND OPTIMIZATION CONTROL OF PROJECT

\begin{tabular}{|c|c|}
\hline ID & Behavioral Competencies \\
\hline $\mathrm{C} 27$ & Sociability \\
\hline $\mathrm{C} 28$ & $\begin{array}{l}\text { Having the leadership and guidance behavior of the } \\
\text { project team }\end{array}$ \\
\hline $\mathrm{C} 29$ & Influence and impact on group projects \\
\hline $\mathrm{C} 30$ & Spirit of unity and empathy \\
\hline C31 & Motivate of project individuals \\
\hline $\mathrm{C} 32$ & $\begin{array}{l}\text { Communication and fair treatment with employees, } \\
\text { customers and stakeholders }\end{array}$ \\
\hline
\end{tabular}

\section{Results}

The initial monitoring criteria were 45 which were later narrowed down to 32 . The results of distribution variables in Kolmogorov-Smirnov test are shown in Table VI. As shown, the assumption of normality for all variables is confirmed. Therefore, t-test can be used to test the hypothesis and the results are shown in Table VII. Results show that individual factors, individual-group factors, performance factors, organizational factors are found to be effective.

TABLE VI. RESULTS OF KOLMOGOROV-SMIRNOV TEST

\begin{tabular}{|c|c|c|c|c|c|}
\hline $\begin{array}{c}\text { Level } \\
\text { of } \\
\text { signific } \\
\text { ance }\end{array}$ & $\begin{array}{c}\text { Statistic } \\
\text { of } \mathbf{z}\end{array}$ & SD & $\begin{array}{c}\text { Avera } \\
\text { ge }\end{array}$ & $\begin{array}{c}\text { Frequ } \\
\text { ency }\end{array}$ & Variable \\
\hline 0.322 & 0.954 & 0.506 & 3.02 & 56 & $\begin{array}{c}\text { Organizational } \\
\text { Factors }\end{array}$ \\
\hline 0.09 & 1.19 & 0.56 & 3.14 & 56 & $\begin{array}{c}\text { Performance } \\
\text { Factors }\end{array}$ \\
\hline 0.11 & 1.47 & 0.454 & 3.49 & 56 & $\begin{array}{c}\text { Individual } \\
\text { factors }\end{array}$ \\
\hline 0.52 & 1.34 & 0.38 & 3.63 & 56 & $\begin{array}{c}\text { Individual- } \\
\text { group factors }\end{array}$ \\
\hline
\end{tabular}

TABLE VII. RESULTS OF HYPOTHESES TESTING

\begin{tabular}{|c|c|c|c|c|c|c|c|c|}
\hline \multicolumn{2}{|c|}{ CI } & \multirow{2}{*}{$\begin{array}{l}\text { Number } \\
\text { of items }\end{array}$} & \multirow{2}{*}{$\begin{array}{c}\text { Degrees } \\
\text { of } \\
\text { freedom }\end{array}$} & \multirow{2}{*}{$\begin{array}{l}\text { Signifi } \\
\text { cance }\end{array}$} & \multirow{2}{*}{$\begin{array}{c}\text { Quantity } \\
\text { of T }\end{array}$} & \multirow{2}{*}{ SD } & \multirow{2}{*}{$\begin{array}{c}\text { Avera } \\
\text { ge }\end{array}$} & \multirow{2}{*}{$\begin{array}{l}\text { Large scale } \\
\text { and subscale }\end{array}$} \\
\hline $\begin{array}{l}\text { Upper } \\
\text { line }\end{array}$ & $\begin{array}{l}\text { Low } \\
\text { line }\end{array}$ & & & & & & & \\
\hline 3.507 & 3.170 & 9 & 55 & 0.000 & 39.748 & 0.628 & 3.339 & individual \\
\hline 3.464 & 3.137 & 6 & 55 & 0.000 & 40.498 & 0.610 & 3.301 & $\begin{array}{c}\text { Individual- } \\
\text { group }\end{array}$ \\
\hline 3.512 & 3.326 & 10 & 55 & 0.000 & 47.259 & 0.533 & 3.369 & performance \\
\hline 3.529 & 3.164 & 7 & 55 & 0.000 & 36.663 & 0.683 & 3.346 & organizational \\
\hline
\end{tabular}

\section{Hybrid Meta-Heuristic IPICEA-g Method Results}

The IPICEA-g hybrid meta-heuristic method is a multiobjective optimization algorithm based on non-dominated relationships and the brushing technique. To implement this algorithm, we need multiple objective functions and the algorithm searches the objective answers to achieve optimal solution space. If factors are defined as $\mathrm{x} 1, \mathrm{x} 2, \mathrm{x} 3$ and $\mathrm{x} 4$ we define objective functions as follows:

$$
\begin{array}{ll}
\max z 1=w 1 x 1 & \max z 2=w 2 \times 2 \\
\max z 3=w 3 \times 3 & \operatorname{maxz} 4=w 4 \times 4
\end{array}
$$

where, w1, w2, w3 and w4 are the weights or importance of individual, individual-group, performance and organizational. The objective is to determine the values of $\mathrm{x} 1, \mathrm{x} 2, \mathrm{x} 3$ and $\mathrm{x} 4$, in a range from 0 to 1 . The values of $x 1, x 2, x 3$ and $x 4$ represent the final rank of the factors obtained by the proposed algorithm. To solve the functions with the proposed algorithm, the initial weights $\mathrm{w} 1, \mathrm{w} 2, \mathrm{w} 3$ and $\mathrm{w} 4$ were determined by combining fuzzy ANP-DEAMATEL and IPICEA-g.

\section{1) The hybrid fuzzy ANP-DEAMATEL approach}

Performance evaluation steps are described below.

a) Formation of decision Network

The network consisted of 3 levels that are used because of computing limited super matrixes and rate of incompatibility.

b) Implementation of dematel fuzzy method
Results are shown in Table VIII. Language assessments are changed to corresponding triangular fuzzy numbers and converted to absolute numbers through CFCS (Converting Fuzzy data into Crisp Scores) and (1) to (9). The primary direct matrix is normalized by (10) and the overall relationship matrix $\mathrm{T}$ is calculated by (11). Afterwards, the matrix $\mathrm{T}$, is placed in super matrixes as matrix W22.

TABLE VIII. LINGUISTIC VARIABLES AND CORRESPONDING FUZZY NUMBERS

\begin{tabular}{|c|c|c|c|}
\hline $\begin{array}{c}\text { Fuzzy } \\
\text { equivalent (b) }\end{array}$ & $\begin{array}{c}\text { Fuzzy } \\
\text { equivalent (a) }\end{array}$ & $\begin{array}{c}\text { Final } \\
\text { equivalent }\end{array}$ & $\begin{array}{c}\text { Linguistic } \\
\text { variable }\end{array}$ \\
\hline$(0,0,0.25)$ & $(0,0.1,0.3)$ & 0 & Very low \\
\hline$(0,0.25,0.5)$ & $(0.1,0.3,0.5)$ & 1 & little \\
\hline$(0.25,0.5,0.75)$ & $(0.3,0.5,0.7)$ & 2 & Average \\
\hline$(0.5,0.75,1)$ & $(0.5,0.7,0.9)$ & 3 & very \\
\hline$(0.75,1,1)$ & $(0.7,0.9,1)$ & 4 & Very much \\
\hline
\end{tabular}

$$
x l_{i j}^{l}=\frac{l_{i j}^{k}-\min _{1 \leq k \leq K} l_{i j}^{k}}{\Delta_{\min }^{\max }}
$$

$x m_{i j}^{k}=\frac{m_{i j}^{k}-\min _{1 \leq k \leq K} l_{i j}^{k}}{\Delta_{\min }^{\max }}$

$$
x r_{i j}^{k}=\frac{r_{i j}^{k}-\min _{1 \leq k \leq K} l_{i j}^{k}}{\Delta_{\min }^{\max }}
$$




$$
\begin{aligned}
& \Delta_{\min }^{\max }=\max r_{i j}^{k} \min l_{i j}^{k} \\
& x s_{i j}^{k}=\frac{x m_{i j}^{k}}{1+x m_{i j}^{k}-x l_{i j}^{k}} \\
& x s_{i j}^{k}=\frac{x r_{i j}^{k}}{1+x r_{i j}^{k}-x m_{i j}^{k}} \\
& x_{i j}^{k}=\frac{x l s_{i j}^{k}\left(1-x l s_{i j}^{k}+x r s_{i j}^{k}\right)+x r s_{i j}^{k} x r s_{i j}^{k}}{1+x r s_{i j}^{k}-x l s_{i j}^{k}} \\
& a_{i j}=\frac{1}{k} \sum_{k}^{1 \leq k \leq K}+B N P_{i j}^{k} \\
& B N P_{i j}^{k}=\min _{i j}^{k}+x_{i j}^{k} \Delta_{\min }^{\max } \\
& X=s \times A \\
& S=\min \left[\frac{1}{\max _{i} \sum_{j=1}^{n} \backslash a_{i j} \backslash}, \frac{1}{\max _{j} \sum_{j=1}^{n} \backslash a_{i j} \backslash}\right]
\end{aligned}
$$

To obtain matrix $\mathrm{T}$, the following formula is used:

$$
\mathrm{T}=\mathrm{X}+\mathrm{X}^{2}+\ldots+\mathrm{X}^{\mathrm{k}}=\mathrm{X}\left(\mathrm{i}+\mathrm{X}+\mathrm{X}^{2}+\ldots+\mathrm{X}^{\mathrm{k}-1}\right)(1-\mathrm{X})(1-\mathrm{X})^{-1}
$$$$
=X\left(1-X^{k}\right)(1-X)^{-1}
$$

If $\lim _{k \rightarrow \infty} X^{k}=[0]_{n x n}$, the overall relationship matrix is obtained by the following equation

$$
\mathrm{T}=\mathrm{X}(1-\mathrm{X})^{-1}
$$

c) Fuzzy ANP process and its combination with fuzzy deamatel

The data collection phase is based on paired comparison questionnaire. For example, a combination of expert opinions for paired comparison of finance criteria perspective is calculated and recorded by using (12). Then, by using the CFCS method, defuzzification was performed and by using (13) the weight of secondary criteria is obtained (incompatibility rate at this point is zero). For the other main criteria, there are similar calculations and the weights of these comparisons are recorded in a column titled local weight of minor factors. The weights as matrix W32 are in the initial super matrix. The main factors will pair. Thus, the initial matrix will form with calculation of W11, W22 and W23.

$$
\begin{gathered}
c_{j}=\sum_{0 \leq i \leq n} T_{i j} \\
r_{i}=\sum_{0 \leq j \leq n} T_{i j}
\end{gathered}
$$

d) Prioritization of key factors and sub-factors and identify of cause-effect factors
To perform the required analysis, prioritization of factors is based on limited weights of super matrix. At the specific table the weight and prioritization of factors are recorded. To identify the causal factors, ri, cj, ri-cj are calculated by using (12) and (13) and their values are recorded. The first step is the formation of decision network and in next stage we described deamatel fuzzy technique for the forming of overall relationship matrix. The deamatel fuzzy relationship matrix obtained by the method is shown in Table IX. As can be seen in Table IX, individual and individual-group dimensions are the reasons and organizational and performance factors are the effects. As mentioned, this matrix w22 is used in initial super matrix of fuzzy ANP method. To the formation of the super matrix we need to form the W32 and W11 matrixes. The W32 matrix was obtained from the comparison of secondary factors. After CFCS defuzzification, the weight for each factor group is calculated with (13). Tables X-XIII show the calculated weight of sub-factors. The weight of calculated factors in Tables $\mathrm{X}$ and XIII is used to form the initial matrix w32. After preparing the matrices W22, W32 and W11, the super initial matrix is prepared and then the limited super matrix is formed. The weight of factors and their prioritization is shown in Table XIV. To identify causal relationships, ri, cj, ri-cj are calculated and the results are shown in the Table XV.

TABLE IX. THE OVERALL RELATIONSHIP MATRIX (OUTPUT OF DEMATEL FUZZY)

\begin{tabular}{|c|c|c|c|c|c|}
\hline $\mathbf{r}_{\mathbf{i}}$ & $\begin{array}{c}\text { Organiza } \\
\text { tional }\end{array}$ & $\begin{array}{c}\text { Perfor } \\
\text { mance }\end{array}$ & $\begin{array}{c}\text { Individual- } \\
\text { group }\end{array}$ & Individual & \\
\hline 1.411 & 0.297 & 0.565 & 0.475 & 0.0742 & individual \\
\hline 3.438 & 0.838 & 0.955 & 0.803 & 0.842 & $\begin{array}{c}\text { Individual- } \\
\text { group }\end{array}$ \\
\hline 0.695 & 0.082 & 0.088 & 0.384 & 0.142 & performance \\
\hline 1.818 & 0.936 & 0.379 & 0.332 & 0.172 & organizational \\
\hline & 2.153 & 19999997. & 1.993 & 1.230 & $\mathrm{c}_{\mathrm{j}}$ \\
\hline & -0.335 & -1.338 & 1.445 & 0.181 & $\mathrm{r}_{\mathrm{i}}-\mathrm{c}_{\mathrm{j}}$ \\
\hline & effect & effect & reason & reason & Type of factor \\
\hline
\end{tabular}

TABLE $\mathrm{X}$. WEIGHT OF THE INDIVIDUAL SUB-INDICES

\begin{tabular}{|c|c|}
\hline Index name & weight \\
\hline Hard work & 0.222 \\
\hline The spirit of achievement & 0.0401 \\
\hline Initiative and innovation & 0.210 \\
\hline Self Confidence & 0.0506 \\
\hline Result oriented & 0.177 \\
\hline Being regulated & 0.114 \\
\hline Having strategic perspectives & 0.087 \\
\hline Spirit of competition & 0.008 \\
\hline Having systematic approaches & 0.0913 \\
\hline
\end{tabular}

TABLE XI. WEIGHT OF INDIVIDUAL SUB-GROUPS INDICATORS

\begin{tabular}{|c|c|}
\hline Index name & weight \\
\hline Sociability & 0.103 \\
\hline $\begin{array}{c}\text { Having the leadership and guidance behavior of } \\
\text { the project team }\end{array}$ & 0.223 \\
\hline $\begin{array}{c}\text { Influence and impact on group projects } \\
\text { Spirit of unity and empathy }\end{array}$ & 0.303 \\
\hline Motivate of project individuals & 0.0809 \\
\hline $\begin{array}{c}\text { Communication and fair treatment with } \\
\text { employees, customers and stakeholders }\end{array}$ & 0.1811 \\
\hline
\end{tabular}


2) The final results of IPICEA-g

The IPICEA-g algorithm determines the optimal values of $\mathrm{x} 1, \mathrm{x} 2, \mathrm{x} 3$ and $\mathrm{x} 4$ ensuring they are less than 1 . To implement the algorithm in this study, a structure for the presentation of the answers with an one-dimensional matrix and a row with 4 cells was used. The values of this matrix represent the values of model variables and they are between 0 and 1 .

The basic steps of the algorithm are as follows:

- First a certain number of answers are produced as the first generation.

- Secondly, with the use of non-dominated solutions they are arranged and ranked.

- Third, using the combination operator, the solutions are combined and produce new solutions.

- In the fourth step, solutions are leveled and according to the number of population size, we select nextgeneration solutions.

- In the fifth step, the solutions identified to optimize border and then the algorithm returns to the second step.

It should be noted that the above actions are repeated until the maximum number of iterations of the algorithm is reached. A single-point crossover operator is also employed. The IPICEA-g algorithm took 500 iterations and after its implementation, 75 responses were reported as optimal solutions. Mean values were calculated as the final weights factors shown in Table XVI

TABLE XII. WEIGHT OF THE SUB-INDICES OF OPERATING PERFORMANCE

\begin{tabular}{|c|c|}
\hline Index name & Weight \\
\hline Project Documentation & 0.0701 \\
\hline Determining the project scope, registration and approval & 0.0225 \\
\hline Choosing project structures & 0.173 \\
\hline Resource planning, registration and approval & 0.121 \\
\hline Select of qualified contractors and vendors & 0.0205 \\
\hline Estimating project costs & 0.193 \\
\hline $\begin{array}{c}\text { Directing, managing of registration process and executing } \\
\text { contracts }\end{array}$ & 0.0419 \\
\hline $\begin{array}{c}\text { Investigate, identify and implementation of necessary } \\
\text { changes in project }\end{array}$ & 0.112 \\
\hline $\begin{array}{c}\text { Coordination between different units and issuing guidelines } \\
\text { which related to projects }\end{array}$ & 0.1675 \\
\hline $\begin{array}{c}\text { Funding, resources and equipment needed to start the } \\
\text { project }\end{array}$ & 0.0785 \\
\hline
\end{tabular}

TABLE XIII. WEIGHT OF THE SUB-INDICES OF ORGANIZATIONAL FACTORS

\begin{tabular}{|c|c|}
\hline Index name & Weight \\
\hline Understanding of project characteristics & 0.223 \\
\hline $\begin{array}{c}\text { Understanding of the assessment process and the Feasibility } \\
\text { of the project }\end{array}$ & 0.0998 \\
\hline Understanding of project structures & 0.104 \\
\hline Understanding the topic of project resources & 0.0752 \\
\hline Understanding the concept of project time & 0.298 \\
\hline Understanding the budget issues and Project costs & 0.109 \\
\hline Understanding the topic of project resources & 0.091 \\
\hline
\end{tabular}

TABLE XIV. MAIN FACTOR WEIGHTS AND THEIR PRIORITIES

\begin{tabular}{|c|c|c|c|c|}
\hline $\begin{array}{c}\text { Main } \\
\text { factors }\end{array}$ & Organizational & Performance & $\begin{array}{c}\text { Individual } \\
\text { - Group }\end{array}$ & Individual \\
\hline $\begin{array}{c}\text { Main } \\
\text { factors } \\
\text { weight }\end{array}$ & 0.0016 & 0.0009 & 0.0041 & 0.0013 \\
\hline
\end{tabular}

TABLE XV. DETERMINE THE CAUSAL FACTORS

\begin{tabular}{|c|c|c|c|c|}
\hline Factor & $\mathbf{r i}$ & $\mathbf{c j}$ & $\mathbf{R i}-\mathbf{c j}$ & $\begin{array}{c}\text { Type of } \\
\text { factor }\end{array}$ \\
\hline individual & 0.01 & 0.0066 & 0.0034 & reason \\
\hline $\begin{array}{c}\text { Individual- } \\
\text { group }\end{array}$ & 0.0315 & 0.0129 & 0.0186 & reason \\
\hline performance & 0.007 & 0.0114 & -0.0043 & effect \\
\hline organizational & 0.0125 & 0.0301 & -0.0177 & effect \\
\hline
\end{tabular}

TABLE XVI. THE FINAL WEIGHT OF THE IPICEA-G ALGORITHM

\begin{tabular}{|c|c|c|c|c|}
\hline $\begin{array}{c}\text { Main } \\
\text { factors }\end{array}$ & Organizational & Performance & $\begin{array}{c}\text { Individual } \\
\text { - Group }\end{array}$ & Individual \\
\hline Weight & 0.409 & 0.287 & 0.487 & 0.318 \\
\hline
\end{tabular}

\section{CONCLUSION}

Project management decisions are influenced by many correlated factors and thus multi-criteria decision-making processes and group decision-making are necessary. The purpose of this paper is to prioritize the factors that have a significant effect on project management. Four different factor groups were identified and evaluated. The data were gathered through questionnaires handed out to expert employees of a certain company. Results are shown and discussed.

\section{REFERENCES}

[1] A. Enshassi, Adnan, S. Mohamed, S. Abushaban, Saleh, "Factors affecting the performance of Construction projects in the Gaza Strip", Journal of Civil Engineering and Management, Vol. 15, No. 3, pp. 269280, 2009

[2] A. Saedghi, A. Kalanaki, A. Noktehdan, A. S. Samghabadi, F. Barzinpour, "Using Bees Algorithm to Solve the Resource Constrained Project Scheduling Problem in PSPLIB", Theoretical and Mathematical Foundations of Computer Science, pp. 486-494, 2011

[3] D. Mirzai Matin, "Identifying The Effective Factors for Cost Overrun and Time Delay in Water Construction Projects", Engineering, Technology \& Applied Science Research, Vol. 6, No. 4, pp. 1062-1066, 2016

[4] S. Milovanovic, "Aims and Critical Success Factors of Knowledge Management System Projects”, Economics and Organization, Vol. 8, No 1, pp. 31-40, 2011

[5] Z. Alias, E. M. A. Zawawi, K. Yusof, N. M. Aris, "Determining Critical Success Factors of Project Management Practice: A Conceptual Framework", Procedia - Social and Behavioral Sciences, Vol. 153, pp. 61-69, 2014

[6] J. M. Lyneis, D. N. Ford, "System dynamics applied to project management: a survey, assessment, and directions for future research", System Dynamics Review, Vol. 23, No. 2-3, pp. 157-189, 2007

[7] Jonas Soderlund, "Knowledge entrainment and project management: The case of large-scale transformation projects", International Journal of Project Management, Vol. 28, No. 2, pp. 130-141, 2010

H. K. Doloi, "Understanding stakeholders' perspective of cost estimation in project management", International Journal of Project Management, Vol. 29, No. 5, pp. 622-636, 2011 
[8] M. Kapsali, "Systems thinking in innovation project management: A match that works", International Journal of Project Management Vol. 29, No. 4, pp 396-407, 2011

[9] K. Artto, I. Kulvik, J. Poskela, V. Turkulainen, "The integrative role of the project management office in the front end of innovation", International Journal of Project Management, Vol. 29, No. 4, pp. 408421,2011

[10] X. Meng, "The effect of relationship management on project performance in construction", International Journal of Project Management, Vol. 30, No. 2, pp. 188-198, 2012

[11] S. Marcelino-Sadaba, A. Pérez-Ezcurdia, A. M. Echeverría Lazcano, P. Villanueva, "Project risk management methodology for small firms",
International Journal of Project Management, Vol. 32, No. 2, pp. 327340,2014

[12] F. Acebes, J. Pajares, J. Manuel Galán, A. Lopez-Paredes, "A new approach for project control under uncertainty. Going back to the basics", International Journal of Project Management, Vol. 32, No. 3, pp 423-434, 2014

[13] M. L. Todorovic, D. C. Petrovic, M. M. Mihic, V. L. Obradovic, S. D. Bushuyev, "Project success analysis framework: A knowledge-based approach in project management", International Journal of Project Management, Vol. 33, No. 4, pp. 772-7832015 